\title{
Highly efficient preparation of active $S$ - phenyl-L-cysteine with tryptophan synthase using a chemoenzymatic method
}

\author{
Lisheng $\mathrm{Xu}^{*}$, Xingtao Zhang, Guizhen Gao and Sun Yue
}

\begin{abstract}
Background: S-Phenyl-L-cysteine is regarded as having potential applicability as an antiretroviral/protease inhibitor for human immunodeficiency virus (HIV). In the present study, optically active S-phenyl-L-cysteine was prepared in a highly efficient manner from inexpensive bromobenzene using tryptophan synthase through a chemoenzymatic method.

Results: The chemoenzymatic method used a four-step reaction sequence. The process started with the reaction of magnesium and bromobenzene, followed by a Grignard reaction, and then hydrolysis and enzymatic synthesis using tryptophan synthase. Through this approach, S-phenyl-L-cysteine was chemoenzymatically synthesized using tryptophan synthase from thiophenol and L-serine as the starting material.
\end{abstract}

Conclusions: High-purity, optically active S-phenyl-L-cysteine was efficiently and inexpensively obtained in a total yield of $81.3 \%$ (> 99.9\% purity).

Keywords: S-phenyl-L-cysteine, Tryptophan synthase, Chemoenzymatic

\section{Background}

S-Phenyl-L-cysteine exhibits the dual advantages of showing long-term effects and having a chemical configuration that is comparable to the anti-AIDS drug nelfinavir. The possibility that S-phenyl-L-cysteine can, like nelfinavir, act as an effective suppressant of HIV protease [1], has increased the importance of developing more tractable approaches for producing these chemical compounds. This is further underscored by the potential for the synthesis of phenyl-L-cysteine and its use in multiple biological activation mechanisms [2-4].

The potential utility of optically active $S$-phenyl-L-cysteine has inspired pharmaceutical chemical scientists to explore new and effective routes to its synthesis. To date, however, only a few synthetic methods have emerged for the preparation of $S$-phenyl-L-cysteine. Previously, $S$ phenyl-L-cysteine was prepared using tryptophan synthase

\footnotetext{
* Correspondence: xulisheng111@163.com

Department of Life and Food Science, Suzhou University, Suzhou 234000, China
}

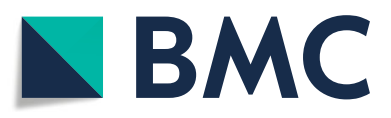

(๑) The Author(s). 2019 Open Access This article is distributed under the terms of the Creative Commons Attribution 4.0 International License (http://creativecommons.org/licenses/by/4.0/), which permits unrestricted use, distribution, and reproduction in any medium, provided you give appropriate credit to the original author(s) and the source, provide a link to the Creative Commons license, and indicate if changes were made. The Creative Commons Public Domain Dedication waiver (http://creativecommons.org/publicdomain/zero/1.0/) applies to the data made available in this article, unless otherwise stated.

in Escherichia coli MT-10242 and Neurospora crassa ATCC 14692. The reaction time for preparing $S$-phenyl$\mathrm{L}$-cysteine using these strategies was $15 \mathrm{~h}[5,6]$, and thus, they were inefficient based on their reaction time requirements. In another case, $S$-phenyl-L-cysteine was prepared by reacting L-cysteine hydrochloride and a soluble singlevalent copper $(\mathrm{Cu})$ salt with the diazonium salt of phenylamine $[7,8]$. The yields of $S$-bromo phenyl-L-cysteine from this copper-mediated reaction, however, were not impressive (37\%). A subsequent effort to synthesize $S$ phenyl-L-cysteine from $S$-bromo phenyl-L-cysteine and mercapturic acid was successful $[9,10]$.

In the present study, $S$-phenyl-L-cysteine was synthesized from thiophenol and L-serine using a recombinant tryptophan synthase (E.C. 4.2.1.20) obtained from E. coli k-12 MG1655. This approach resulted in high yields of optically active S-phenyl-L-cysteine (5) (Fig. 1). The products from the reaction of thiobenzyl alcohol and ethanethiol were then isolated to demonstrate the enzymatic synthesis of the corresponding S-substituted L-cysteines [11]. Our findings indicate that the tryptophan synthase from E. coli $\mathrm{k}-12$ MG1655 effectively catalyses the synthesis of L-cysteine from L-serine and sodium hydrosulfide [12]. 


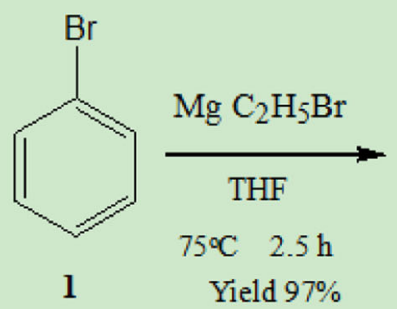<smiles>O=[W]c1ccccc1</smiles>
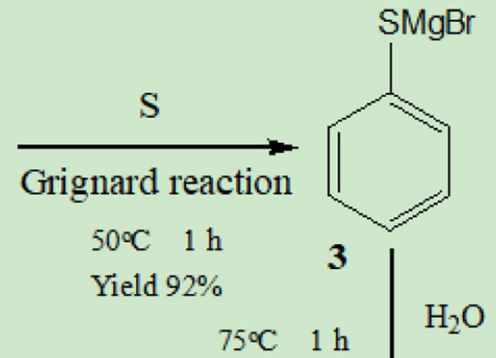

Yield 95\%

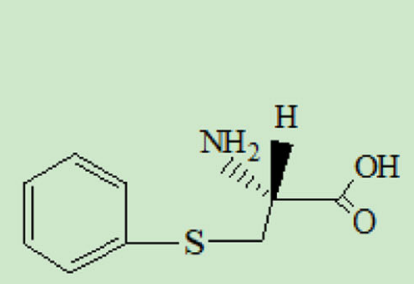

5

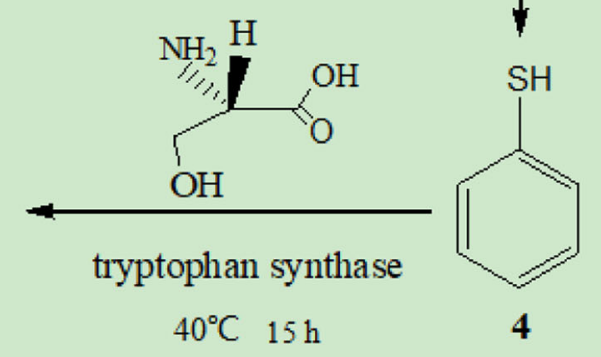

Yield 96\%

Fig. 1 Chemoenzymatic preparation of optically active S-phenyl-L-cysteine

\section{Results}

Preparation of phenylmagnesium bromide (2)

Phenylmagnesium bromide was prepared using magnesium and bromobenzene. Phenyl magnesium bromide was separated through filtration (2) (yield: 97\%). ${ }^{1} \mathrm{H}$ NMR $\left(400 \mathrm{MHz}, \mathrm{CDCl}_{3}\right): \delta 7.01 \sim 7.66(\mathrm{~m}, 5 \mathrm{H})$ Combustion elemental analysis calculated (Anal. Calcd) for $\mathrm{C}_{6} \mathrm{H}_{5} \mathrm{MgBr}$ : C, 39.99; H, 2.78; Br, 43.88. Found: C, 39.96; H, 2.77; Br, 43.89. ESI-MS (m/z): $181.0121[\mathrm{M}+\mathrm{H}]^{+}$. The calculated mass of phenyl magnesium bromide: 180.1141 .

\section{Preparation of thiophenyl magnesium bromide (3)}

Thiophenyl magnesium bromide was prepared by using sulfur and phenyl magnesium bromide. Thiophenyl magnesium bromide (3) was formed after cooling (yield: 92\%). ${ }^{1} \mathrm{H}$ NMR (400 MHz, $\mathrm{CDCl}_{3}$ ): $\delta$ 7.29-7.32 (m, 5H). Anal. Calcd for $\mathrm{C}_{6} \mathrm{H}_{5} \mathrm{SMgBr}$ : C, 33.96; $\mathrm{H}, 2.35 ; \mathrm{S}, 15.09$; Br, 37.27. Found: C, 33.94; H, 2.34; S, 15.11; Br, 37.26. ESI-MS $(\mathrm{m} / \mathrm{z}): 213.0311[\mathrm{M}+\mathrm{H}]^{+}$. The calculated mass of phenyl magnesium bromide: 212.7812 .

\section{Preparation of thiophenol (4)}

Thiophenol (4) was isolated by distillation of the upper layer of the solution. Thiophenol (4) was obtained in 95\% yield. ${ }^{1} \mathrm{H}$ NMR (400 $\left.\mathrm{MHz}, \mathrm{CDCl}_{3}\right): \delta 6.97 \sim 7.42(\mathrm{~m}$, $5 \mathrm{H}), 3.40(\mathrm{~s}, 1 \mathrm{H})$ Anal. Calcd for $\mathrm{C}_{6} \mathrm{H}_{6} \mathrm{~S}: \mathrm{C}, 65.45 ; \mathrm{H}$, 5.45; S, 29.10. Found: C, 65.44; H, 5.49; S, 29.07. ESI-MS $(\mathrm{m} / \mathrm{z}): 111.1821\left[\mathrm{M}+\mathrm{H}^{++}\right.$. The calculated mass of thiophenol: 111.0172 .

\section{Preparation of S-phenyl-L-cysteine (5)}

The activity of tryptophan synthase is dependent on factors such as substrate concentration, temperature, and $\mathrm{pH}$. Tryptophan synthase was directly mixed with substrate $(180 \mathrm{mmol} / \mathrm{L})$ at $\mathrm{pH}$ values from 6 to 11 at $40{ }^{\circ} \mathrm{C}$, and the reactions were allowed to proceed for 14 $\mathrm{h}$. We found the optimal initial $\mathrm{pH}$ for the synthesis of S-phenyl-L-cysteine was 9.0 (Fig. 2). The effect of temperatures from $10{ }^{\circ} \mathrm{C}$ to $60{ }^{\circ} \mathrm{C}$ on S-phenyl-L-cysteine synthesis was investigated. The best yield of S-phenylL-cysteine was achieved at $40{ }^{\circ} \mathrm{C}$ (Fig. 3). The effect of substrate concentrations from $50 \mathrm{mmol} / \mathrm{L}$ to $400 \mathrm{mmol} /$ $\mathrm{L}$ on S-phenyl-L-cysteine synthesis was investigated. The optimal substrate concentration was $180 \mathrm{mmol} / \mathrm{L}$ (Fig. 4). Tryptophan synthase was directly mixed with thiophenol and L-serine under the optimum reaction conditions of $\mathrm{pH} 9.0,40{ }^{\circ} \mathrm{C}$, using Trion $\mathrm{X}-100$ at $0.02 \%$ (Fig. 5). After drying the crystals, $16.04 \mathrm{~g}$ of $S$-phenyl-Lcysteine was obtained (yield: 96\%). The purity of Sphenyl-L-cysteine was $99.9 \%$ as verified by HPLC (Fig. 6). Specific rotation $[\alpha] D^{20}=+73 \sim+75^{\circ}(c=1$, $\left.1.5 \mathrm{M} \mathrm{H}_{2} \mathrm{SO}_{4}\right) .{ }^{1} \mathrm{H}$ NMR $\left(400 \mathrm{MHz}, \mathrm{D}_{2} \mathrm{O}\right): \delta 2.81(\mathrm{dd}$, $\mathrm{J}=7.82,3.13 \mathrm{~Hz}, \mathrm{H}), 2.88(\mathrm{~d}, \mathrm{~J}=3.13 \mathrm{~Hz}, \mathrm{H}), 3.13(\mathrm{~d}, \mathrm{~J}=$ $7.82 \mathrm{~Hz}, \mathrm{H}$ ), $7.21 \sim 7.39$ (m, PhH, 5H) (Fig. 7). Anal. Calcd for $\mathrm{C}_{9} \mathrm{H}_{11} \mathrm{NO}_{2} \mathrm{~S}$ : C, 54.75; $\mathrm{H}, 5.57 ; \mathrm{N}, 7.09$. 


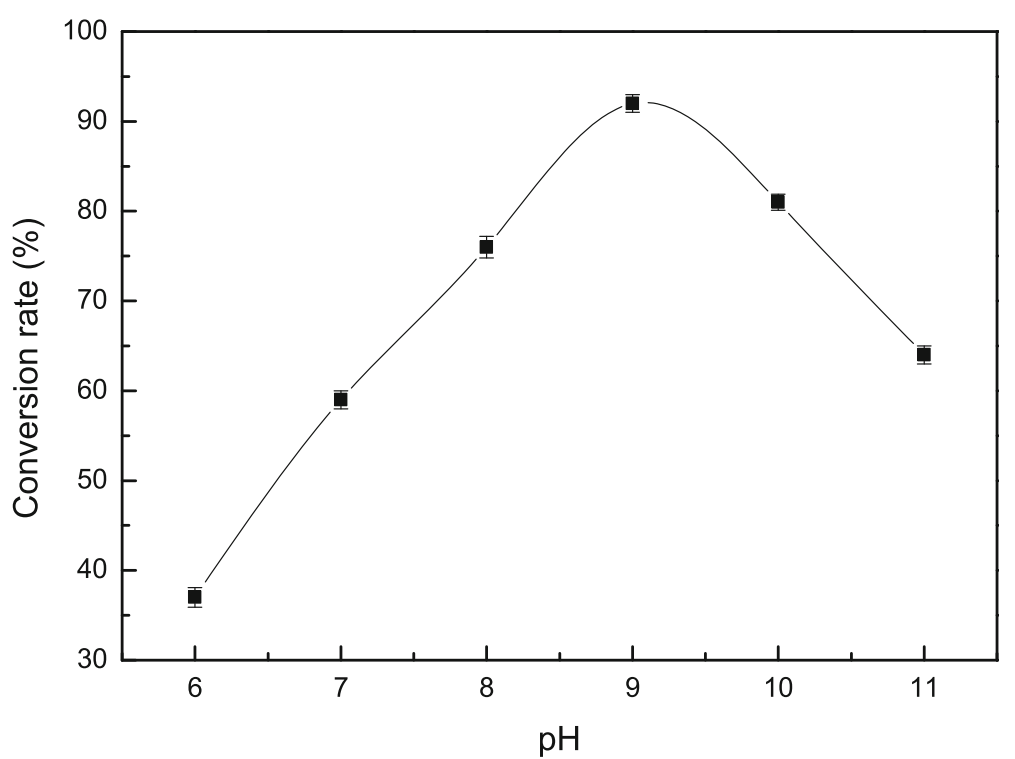

Fig. 2 Effect of $\mathrm{pH}$ on the tryptophan synthase-catalysed synthesis of S-phenyl-L-cysteine. Tryptophan synthase was directly mixed with the substrate $(180 \mathrm{mmol} / \mathrm{L})$ at $40^{\circ} \mathrm{C}$ for $14 \mathrm{~h}$ using Trion $\mathrm{X}-100$ at $0.02 \%$

Found: C, 54.72; H, 5.52; N, 7.05. ESI-MS (m/z): 198.254 $[\mathrm{M}+\mathrm{H}]^{+}$(Fig. 8). The calculated mass of Sphenyl-L-cysteine: 197.2312.

\section{Discussion}

Tryptophan is a naturally occurring amino acid that is synthesized by tryptophan synthase in plants and microorganisms. While indole-3-glycerol phosphate has been synthesized by the $\alpha$-subunit of tryptophan synthase, it has not been used for the synthesis of tryptophan analogues. A series of analogues of L-tryptophan were synthesized through a $\beta$-reaction using tryptophan synthase [13]. Likewise, we reported the synthesis of $S$-phenyl-L-cysteine using tryptophan synthase from L-serine derived from the hydrolysis of keratin from industrial wastewater and thiophenol [14]. High-purity tryptophan was produced in excellent yield.

Thiophenols are synthesized from phenols through a reaction with thiophosgene to form an aryl chlorothionoformate [15] that is then reacted with hydrogen sulfide

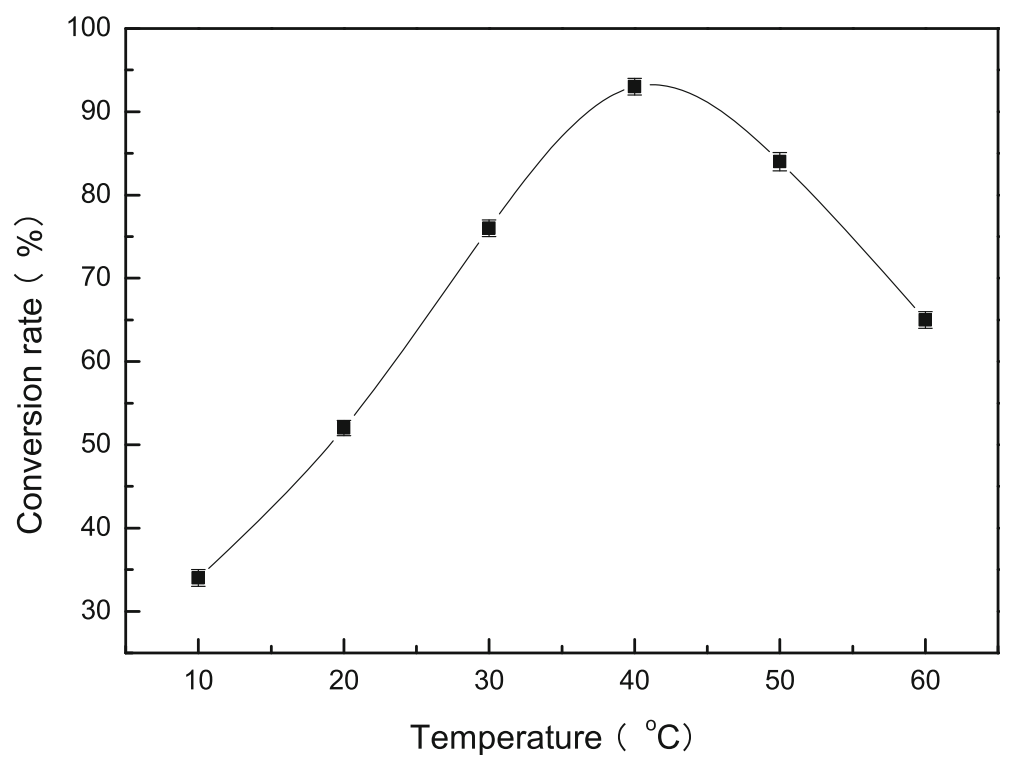

Fig. 3 Effect of temperature on the tryptophan synthase-catalysed synthesis of S-phenyl-L-cysteine. Tryptophan synthase was directly mixed with the substrate $(180 \mathrm{mmol} / \mathrm{L})$ at $\mathrm{pH} 9.0$ for $14 \mathrm{~h}$ using Trion $\mathrm{X}-100$ at $0.02 \%$ 


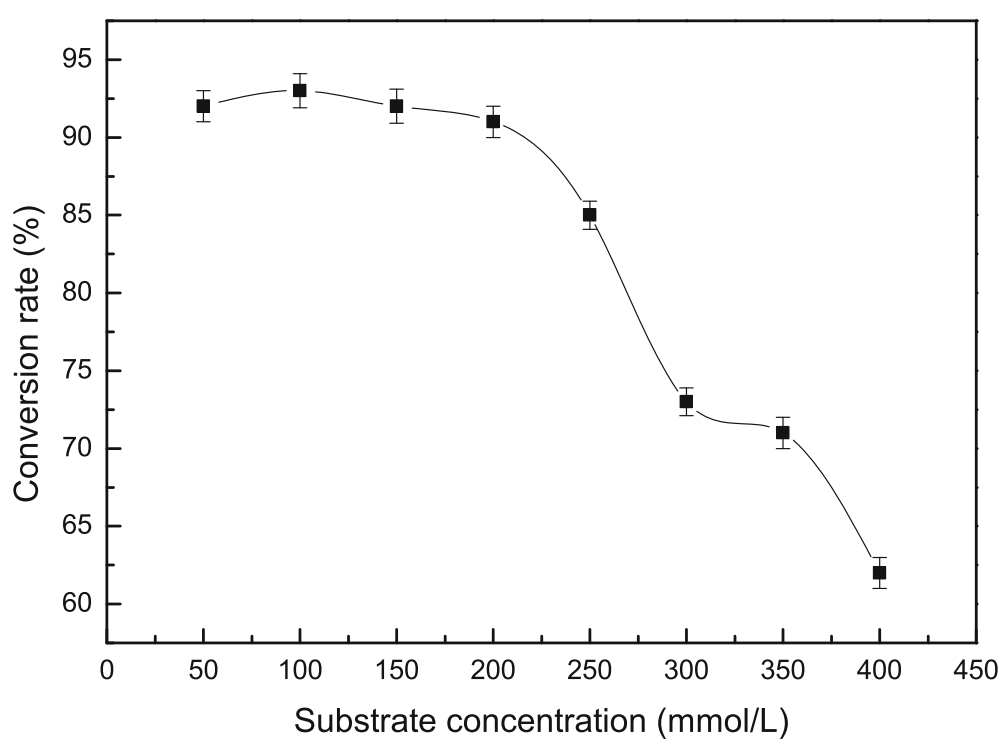

Fig. 4 Effect of substrate concentration on the tryptophan synthase-catalysed synthesis of S-phenyl-L-cysteine. Tryptophan synthase was directly mixed with the substrate at $40^{\circ} \mathrm{C}$ and $\mathrm{pH} 9.0$ for $14 \mathrm{~h}$ using Trion $\mathrm{X}-100$ at $0.02 \%$

over an absorptive catalyst, such as activated carbon or calcined petroleum coke [16]. The production of a thiophenol involves the reaction of hydrogen sulfide and a source of hydrogen with a halogenated aromatic compound [17]. All of the above methods require heating at a high temperature and have high production costs.

In this study, thiophenol was formed by a simple, 4-step sequence involving the reaction of magnesium and bromobenzene (1) to form phenylmagnesium bromide (2), a Grignard reaction with sulfur to form thiophenyl magnesium bromide (3), and hydrolysis using sulfuric acid to form the resulting thiophenol (4).

\section{Conclusions}

Optically active $S$-phenyl-L-cysteine (5) was synthesized using tryptophan synthase from low-cost bromobenzene (1). Tryptophan synthase was successfully applied for the preparation of optically active $S$-phenyl-L-cysteine in excellent purity (>99.9\%) and high yield (81.3\%).

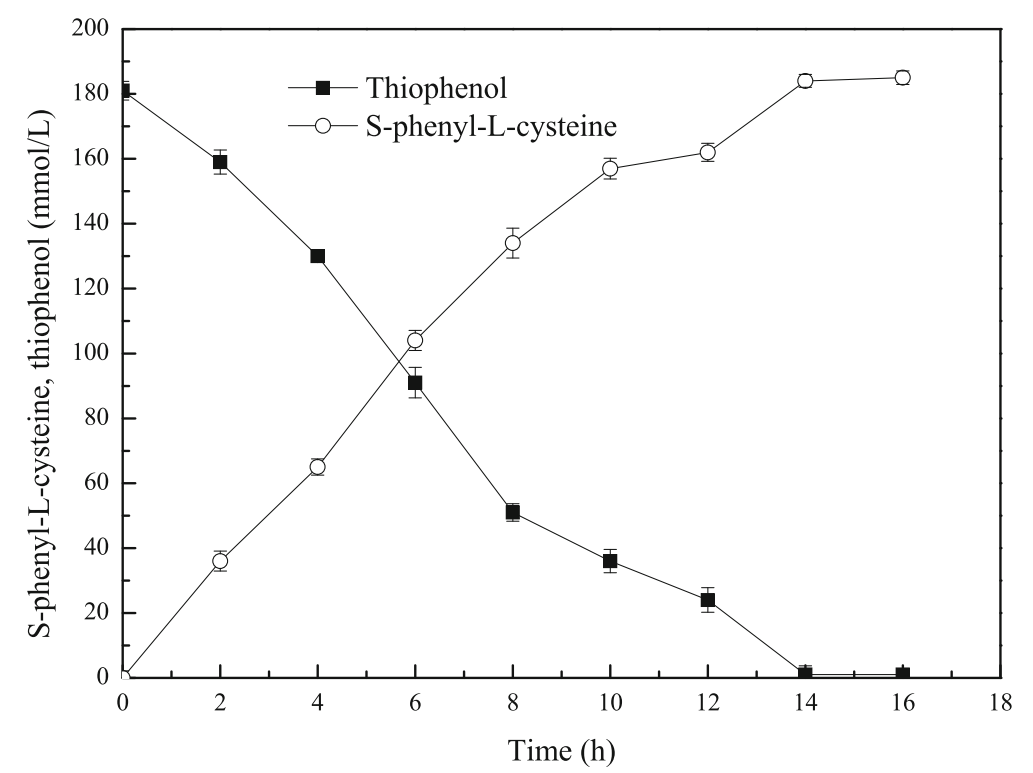

Fig. 5 Changes in the concentrations of S-phenyl-L-cysteine and thiophenol. The concentrations of S-phenyl-L-cysteine (o) and phenylthiol alcohol (-) were measured at different times 

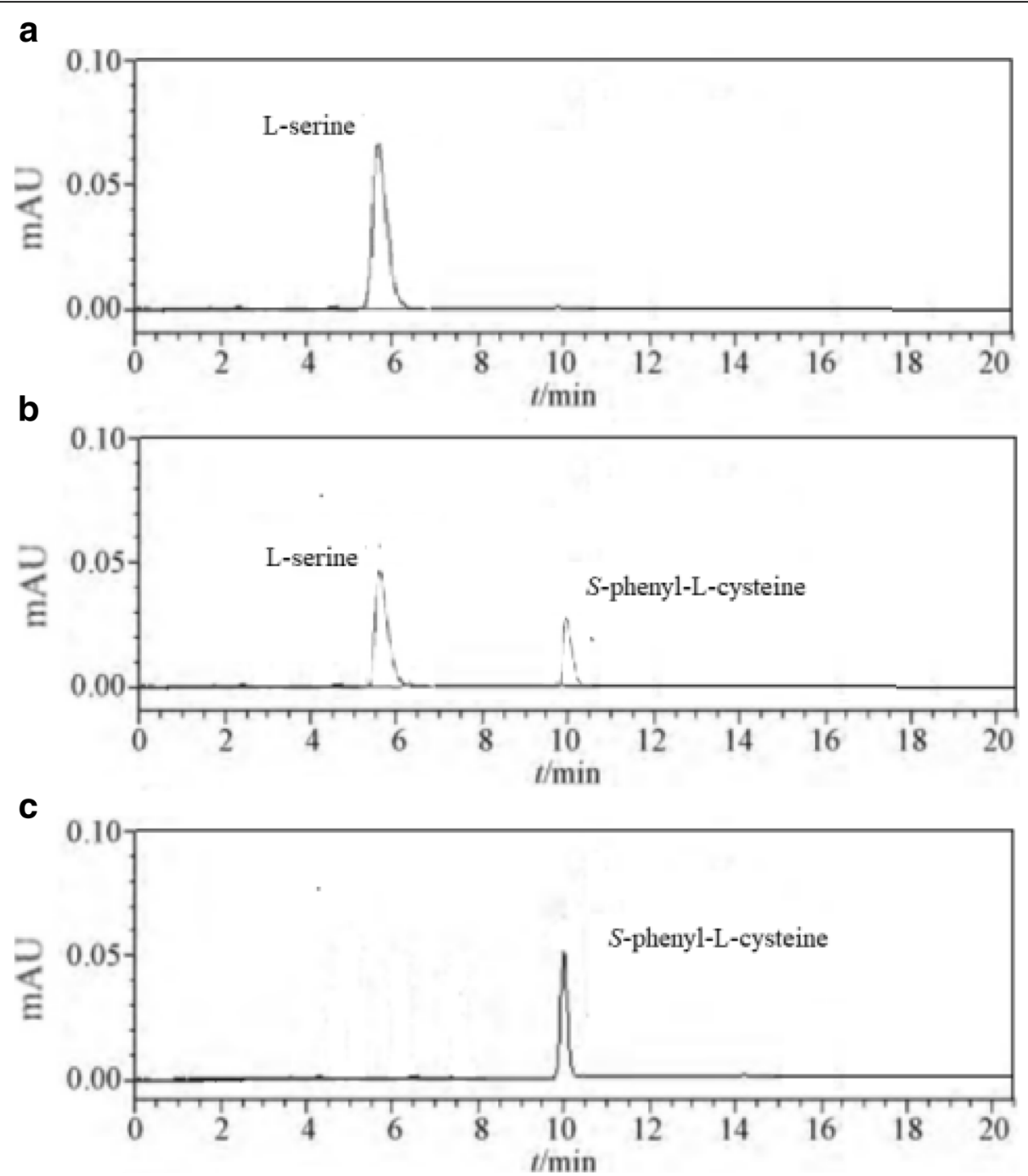

Fig. 6 HPLC chromatograms of S-phenyl-L-cysteine. (Reaction times a: 0 h, b: 6 h, and c: 8 h)

\section{Methods}

\section{Reagents and instruments}

All chemical reagents were of analytical grade and were purchased from Aladdin Reagent Corporation (Shanghai, China). The chemical compositions of $S$ phenyl-L-cysteine and thiophenol were verified using HPLC (Shimadzu High-Performance Liquid Chromatograph, Kyoto, Japan). ${ }^{1} \mathrm{H}$ NMR spectra were recorded on a Bruker DRX500 (500 MHz; Tokyo, Japan). Optical rotations were recorded using a WZZ-2B polarimeter (Hinotek, Ningbo, China). Mass spectra were recorded on a Mariner ESI-TOF mass spectrometer (Applied Biosystems, Foster City, CA). The enantiomeric purities of the residual substrate were determined as described by Zheng [18]. Elemental compositions were measured using a trace element auto analyser (EA3000 type).

\section{Enzymes}

The gene encoding tryptophan synthase was cloned from E. coli k-12 MG1655. The E. coli strain BL21(DE3) carrying the recombinant plasmid Duet-trpBA (DM206) was constructed in our laboratory (Fig. 9). Tryptophan synthase appeared as an intense protein band with an apparent molecular mass of approximately $45 \mathrm{kDa}$. The amplified PCR product was separated by agarose gel electrophoresis. The gene encoding tryptophan synthase was $2 \mathrm{~kb}$. A loopful of strain culture was used to inoculate $40 \mathrm{ml}$ of LB broth in a $200 \mathrm{ml}$ Erlenmeyer flask. The flask was incubated at $30^{\circ} \mathrm{C}$ for $12 \mathrm{~h}$ on a rotary shaker at $170 \mathrm{rpm}$. Tryptophan synthase was purified according to the protocol described by Tsunehiko et al. [19]. The cells containing tryptophan synthase were placed in 40 $\mathrm{ml}$ of $40 \mathrm{mM}$ Tris- $\mathrm{HCl}(\mathrm{pH} 7.5)$ and then ultrasonicated at $4{ }^{\circ} \mathrm{C}$. The cell-free extracts of tryptophan synthase 


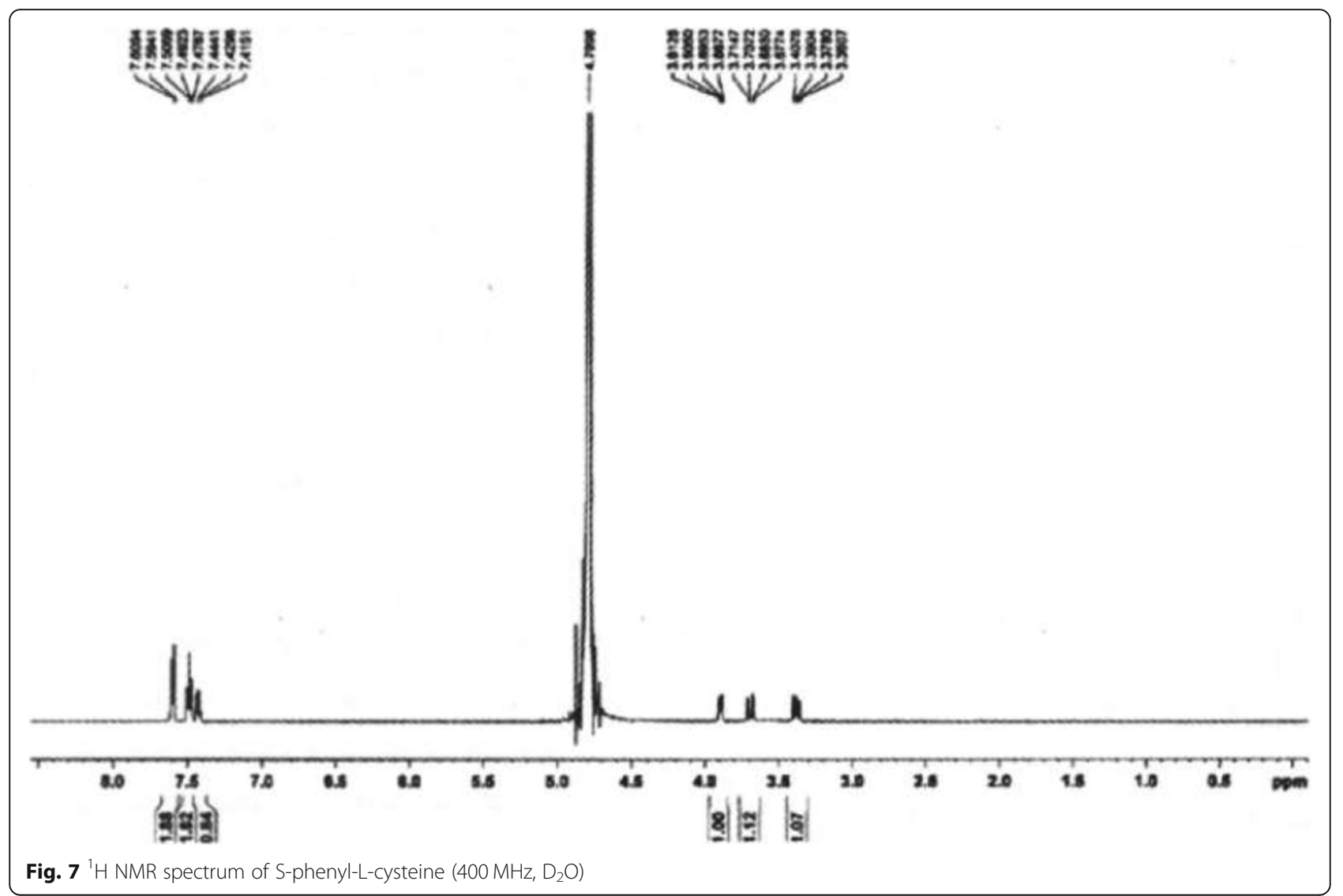

were then fractionated using $\left(\mathrm{NH}_{4}\right)_{2} \mathrm{SO}_{4}(20-60 \%)$. The active fractions of tryptophan synthase were collected by $\left(\mathrm{NH}_{4}\right)_{2} \mathrm{SO}_{4}$ sedimentation; they were then applied to a DEAE-Sepharose CL-6B column $(4.5 \times 85 \mathrm{~cm}$; Seikagaku Kogyo, Japan) and equilibrated with $45 \mathrm{mM}$ Tris- $\mathrm{HCl}$ ( $\mathrm{pH}$ 7.5) containing $1 \mathrm{mM}$ manganese sulfate. The tryptophan synthase was eluted using $45 \mathrm{mM}$ Tris- $\mathrm{HCl}$ (pH 7.5) containing $1 \mathrm{mM}$ manganese sulfate. The final tryptophan synthase sample was found to be homogeneous based on SDS-polyacrylamide gel electrophoresis. Following the addition of $\left(\mathrm{NH}_{4}\right)_{2} \mathrm{SO}_{4}$ to the final tryptophan synthase sample, it was stored at $4{ }^{\circ} \mathrm{C}$ in buffer containing $45 \mathrm{mM}$ Tris- $\mathrm{HCl}(\mathrm{pH} 7.5)$ with $1 \mathrm{mM}$ manganese sulfate, which is the buffer system that had been used throughout the tryptophan synthase purification procedure. The activity of tryptophan synthase was determined by the conversion rate of $S$-phenyl-L-cysteine. Tryptophan synthase was directly mixed with the substrate

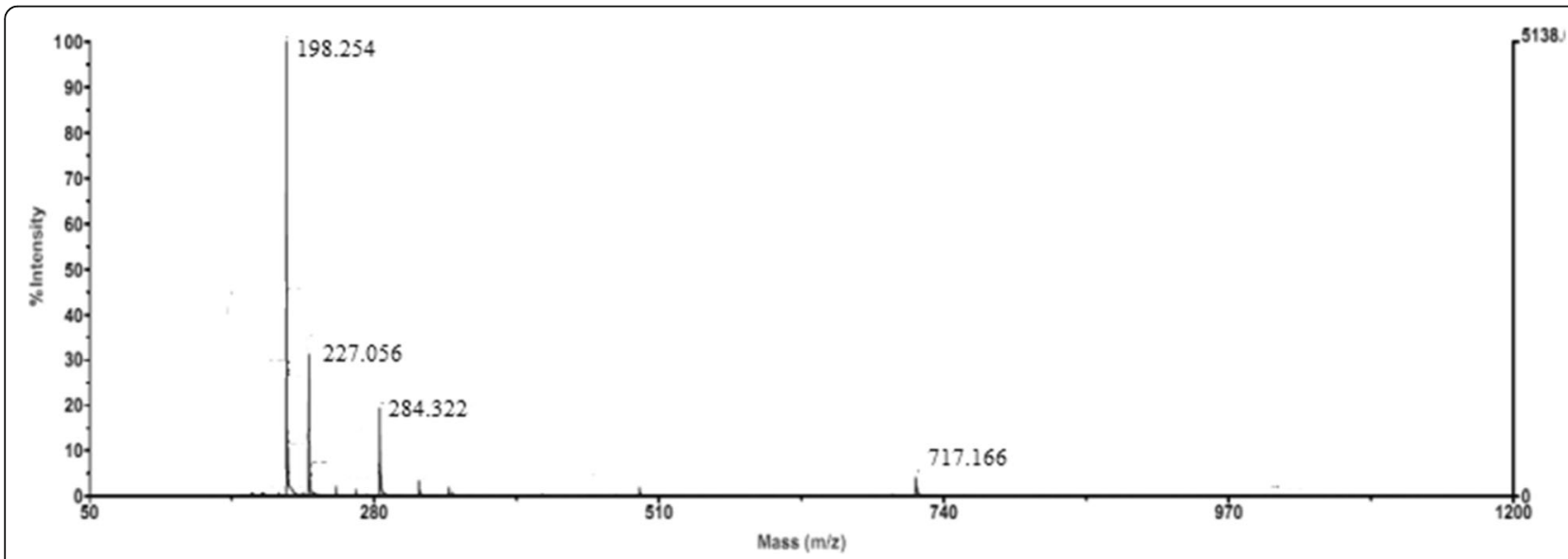

Fig. 8 Mass spectrum of S-phenyl-L-cysteine 


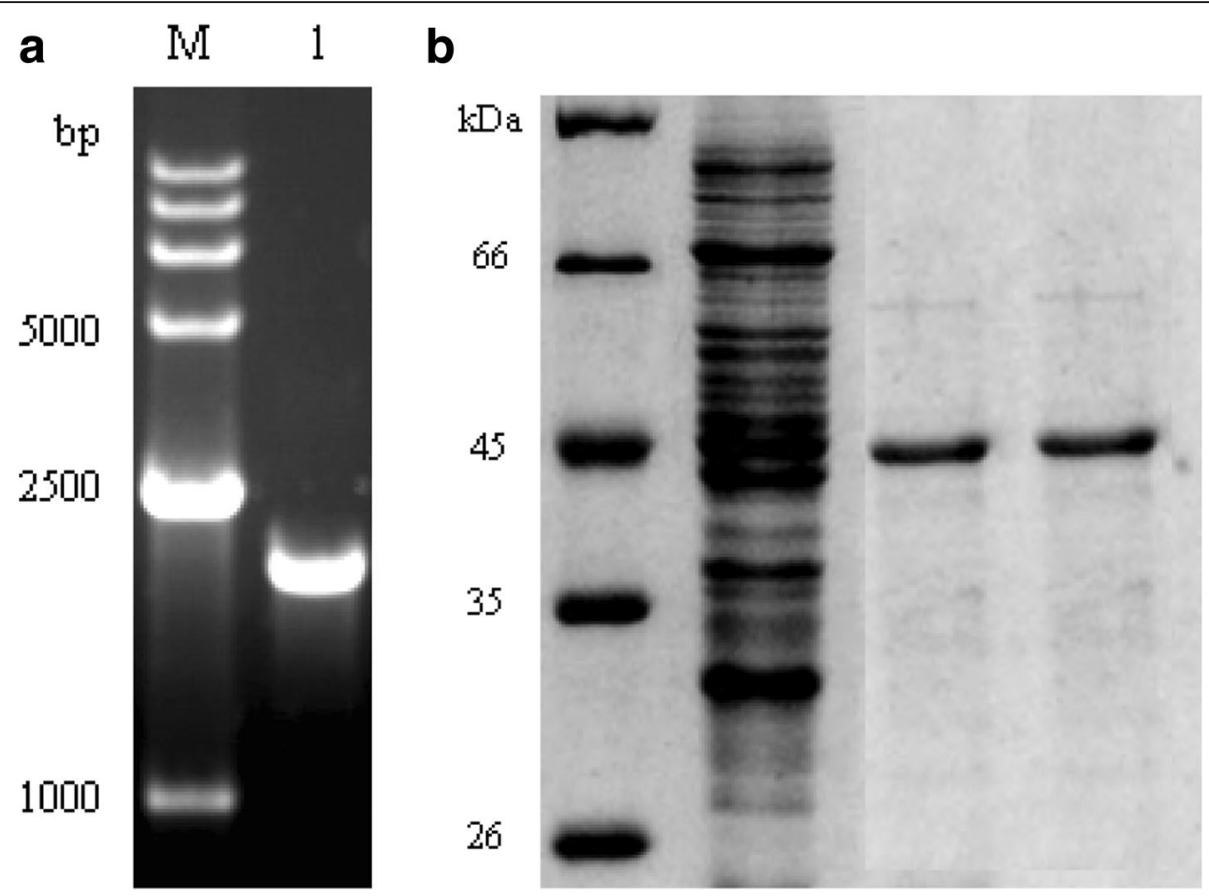

Fig. 9 a. Agarose gel electrophoresis analysis of tryptophan synthase gene. Lane M: nucleic acid molecular mass standards. Lane 1: the product of tryptophan synthase PCR. b. SDS-PAGE analysis of recombinant E. coli expressing recombinant tryptophan synthase

$(100 \mathrm{mmol} / \mathrm{L})$ at $40^{\circ} \mathrm{C}$ and $\mathrm{pH} 9.0$ for $14 \mathrm{~h}$ using Trion $\mathrm{X}-100$ at $0.02 \%$.

\section{Preparation of thiophenol (4)}

The preparation of thiophenol included three steps: (1) the reaction of magnesium and bromobenzene, which formed phenyl magnesium bromide; (2) a Grignard reaction with sulfur, which formed thiophenyl magnesium bromide; and (3) the hydrolysation of thiophenyl magnesium bromide by sulfuric acid, which afforded thiophenol (4).

For the first step, bromobenzene was dissolved in THF. Bromobenzene (25\%) was added to the reactor containing magnesium. Bromobenzene (15.6 g) was dissolved in tetrahydrofuran (THF, $50 \mathrm{~mL}$ ). A quarter of the bromobenzene solution and the magnesium (3.07 g) were added to the reactor. The reactor was stirred at $170 \mathrm{rpm}$ under $\mathrm{N}_{2}$. Bromoethane $(1.66 \mathrm{~g})$ in THF $(5 \mathrm{~mL})$ was added into the reactor. The mixture was heated at $75^{\circ} \mathrm{C}$. The remaining bromobenzene in THF was dropped into the reactor after cooling. The reactor was stirred at $75^{\circ} \mathrm{C}$ for $150 \mathrm{~min}$. After cooling the filtrate to $30{ }^{\circ} \mathrm{C}$, the formed phenyl magnesium bromide (2) was separated by filtration.

For the second step, sulfur (4.05 g) was dropped into the reactor with phenyl magnesium bromide (2). The reactor was stirred at $50{ }^{\circ} \mathrm{C}$. Thereafter, the mixture was heated at reflux for $1 \mathrm{~h}$. Thiophenyl magnesium bromide (3) was formed upon cooling.
In the third step, thiophenyl magnesium bromide was hydrolysed by sulfuric acid. Sulfuric acid ( $44 \mathrm{ml}$; $2.27 \mathrm{M})$ was dropped into the reactor over $20 \mathrm{~min}$ at $60^{\circ} \mathrm{C}$. The reactor was stirred at $75^{\circ} \mathrm{C}$ for an additional $60 \mathrm{~min}$. Another portion of sulfuric acid $(14.4 \mathrm{ml} ; 6.93 \mathrm{M})$ was dropped into the reactor over $20 \mathrm{~min}$. The resulting solution formed two layers.

\section{The enzymatic step}

In this study, thiophenol (4) was prepared through three simple steps (Fig. 1). S-Phenyl-L-cysteine (5) was synthesized using tryptophan synthase. In the biosynthetic reaction, the reactor was stirred at $170 \mathrm{rpm}$ under $\mathrm{N}_{2}$. The content of thiophenol gradually decreased as $S$-phenyl-Lcysteine was formed over $14 \mathrm{~h}$. After $14 \mathrm{~h}, \mathrm{HCl}$ was added to the enzymatic reaction to adjust its $\mathrm{pH}$ to 0.5 , generating S-phenyl-L-cysteine. The enzymatic reaction mixture was filtered, and the filtrated was adjusted to $\mathrm{pH} 2.5$ using sodium hydroxide. After cooling the filtrate to $10^{\circ} \mathrm{C}$, the target product ( $S$-phenyl-L-cysteine) was obtained.

\section{Abbreviations}

E. coli: Escherichia coli; HIV: Human immunodeficiency virus

\section{Acknowledgements}

Not applicable.

\section{Authors' contributions}

Conceived and designed the experiments: LX. Performed the experiments: GG. Analysed the data: SY, ZX. All authors read and approved the final manuscript. 


\section{Funding}

This work was supported by the Academic Leader Program of Suzhou University (2018XJXS02), the Technology Planning Project of Suzhou (SZ2017GG18), and the Key Project of Natural Science Research in Colleges and Universities in Anhui Province (KJ2017A440, KJ2017ZD36). Natural science research projects of Suzhou University(2017ykf01). Dual-ability teaching team of Suzhou University (2019XJSN05), Professional leader of suzhou University (2019XJZY10), Anhui Quality Engineering Project

(2018sjjd044、2018mooc388). No funding body had any role in the design of the study and collection, analysis, and interpretation of data and in writing the manuscript.

\section{Availability of data and materials}

The datasets used and/or analysed in the current study are available from the corresponding author upon reasonable request.

\section{Ethics approval and consent to participate}

Not applicable.

\section{Consent for publication}

Not applicable.

\section{Competing interests}

The authors declare that they have no competing interests.

Received: 14 March 2019 Accepted: 1 July 2019

\section{Published online: 18 July 2019}

\section{References}

1. Fukuda, K., Fukuhara, N., \& Mitsui. T.C. Production of S-phenyl-L-cysteine. PCT patent specification Japan patent 9084592A, 1996.

2. Marzoni G, Kaldor SW, Trippe AJ, Shamblin BM, Fritz JE. A convenient large scale synthesis of N-CBZ-(S-phenyl)-L-cysteine. Synth Commun. 1995;25: 2475-82.

3. Kaldor SW, Kalish VJ, Davies JF, Shetty BV, Fritz JE, Appelt K, Burgess JA, Campanale KM, Chirgadze NY, Clawson DK, Dressman BA, Hatch SD, Khalil DA, Kosa MB, Lubbehusen PP, Muesing MA, Patick AK, Reich SH, Su KS, Tatlock JH. Viracept (nelfinavir mesylate, AG1343):a potent, orally bioavailableinhibitor of HIV-1 protease. J Med Chem. 1997:40:3979-85.

4. Dua RK, Taylor EW, Phillips RS. S-aryl-L-cysteine S,S-dioxides: design, synthesis and evaluation of a new class of inhibitors of kynureninase. J Am Chem Soc. 1993;115:1264-70.

5. Rooseboom M, Vermeulen NPE, Durgut F, Commandeur JNM. Comparative study on the bioactivation mechanisms and cytotoxicity of Te-phenyl-Ltellurocysteine, se-phenyl-L-selenocysteine, and S-phenyl-L-cysteine. Chem Res Toxicol. 2002;15:1610-8.

6. Wieland T. Peptides of poisonous amanita mushrooms. New York: SpringerVerlag; 1986. p. 30-60.

7. Zhang G, Zheng Y, Pan L. Preparation of N-benzyloxycarbonyl-S-benzyl-Lcysteine. PCT patent specification China patent1552697A; 2004.

8. Wolfe $\mathrm{S}$, Kazmaier PM, Auksi H. Cyclization of cysteinylglycine sulfoxides under pummerer reaction conditions. Can J Chem. 1979:57:2412-25.

9. Zbarsky SH, Young L. Mercapturic acids I: the synthesis of phenyl-L-cysteine and L-phenylmercapturic acid. J Biol Chem. 1943;151:212-5.

10. Doodman L, Leonard OR, Baker BR. Potential aanticancer agents. V. some sulfur-substituted derivatives of cysteine. J Org Chem. 1958;23:1251-7.

11. Nobuyoshi E, Hidehiko T, Wilson ME, et al. Enzymatic synthesis of Ssubstituted L-cysteines with tryptophan synthase of Escherichia coli. Agric Biol Chem. 1983:47(12):2861-4

12. Ken-ichi I, Nakamura T, Shimada M, et al. Enzymatic production of L-cysteine with tryptophan synthase of Escherichia coli. J Ferment Bioeng. 1989;67(3): 169-72.

13. Phillips RS. Synthetic applications of tryptophan synthase. Tetrahedron Asymmetry. 2004;(18):2787-92.

14. Xu LS, Wang ZY, Mao PT, Liu JZ, Zhang HJ, Liu Q, Jiao QC. Enzymatic synthesis of S-phenyl-I-cysteine from keratin hydrolysis industries wastewater with tryptophan synthase. Bioresour Technol. 2013;133:635-7.

15. Elliott B. Preparation of thiophenols from phenols. PCT patent specification U.S.a patent 4754072A, 1987

16. Shim, K.S., Skrzec. A.E. Process for preparing thiophenols. PCT patent specification U.S.a patent 4284817A, 1977.
17. Skrzec A.E. Production of thiophenol. PCT patent specification Canada patent 1155140A2, 1982

18. Zheng RC, Zheng YG, Shen YC. A simple method to determine concentration of enantiomers in enzyme-catalyzed kinetic resolution. Biotechnol Lett. 2007;29:1087-90.

19. Tsunehiko K, Erich S, Sigrid E, Helmut H. Purification and properties of tryptophan-synthase-inactivating enzymes from yeast. Eur J Biochem. 1972; 27:520-6.

\section{Publisher's Note}

Springer Nature remains neutral with regard to jurisdictional claims in published maps and institutional affiliations.
Ready to submit your research? Choose BMC and benefit from:

- fast, convenient online submission

- thorough peer review by experienced researchers in your field

- rapid publication on acceptance

- support for research data, including large and complex data types

- gold Open Access which fosters wider collaboration and increased citations

- maximum visibility for your research: over $100 \mathrm{M}$ website views per year

At $\mathrm{BMC}$, research is always in progress.

Learn more biomedcentral.com/submissions 